Article

\title{
Assessment of Energy-Saving Practices of the Hospitality Industry in Macau
}

\author{
Xu Wang ${ }^{1}$ (i), NaiQi Wu ${ }^{1,2, *(\mathbb{D})}$, Yan Qiao ${ }^{1}$ and QingBin Song ${ }^{3}$ \\ 1 Institute of Systems Engineering, Macau University of Science and Technology, Macau 999078, China; \\ keep9s@foxmail.com (X.W.); yqiao@must.edu.mo (Y.Q.) \\ 2 School of Electro-Mechanical Engineering, Guangdong University of Technology, Guangzhou 510006, China \\ 3 Macau Environmental Research Institute, Macau University of Science and Technology, Macau 999078, \\ China; qbsong@must.edu.mo \\ * Correspondence: nqwu@must.edu.mo; Tel.: +853-8897-1991
}

Received: 17 December 2017; Accepted: 17 January 2018; Published: 19 January 2018

\begin{abstract}
Macau is building a world tourism and leisure center. In the context of flourishing hospitality development, energy issues have attracted more and more attention in recent years. On the basis of the field survey of 28 hotels, an evaluation index system is built to assess the status of energy-saving and environmental protection practices in the hospitality industry in Macau. This system is built by selecting some credits from Leadership in Energy and Environmental Design (LEED) and adding several new indices according to the social and economic characteristics of Macau. The results show that the hotels have made significant efforts to improve the energy efficiency in recent years. A total of $71.4 \%$ of the hotels have formulated and implemented the energy-saving and environmental protection programs. However, there is an apparent gap in energy and environmental performance between different star-level hotels. The higher is the star-level of a hotel, the higher enthusiasm on energy-saving a hotel has, e.g., $63.6 \%$ of the 5 -star hotels carried out the carbon auditing and energy management measures, but there is no 2-star hotel that adopted them. The energy-saving performance can be great improved if more efforts are made in the future, especially for the 2-star hotels. Finally, we put forward some suggestions for how to bridge this gap and present a possible roadmap for the further improvement of energy efficiency of the hotel industry in Macau. The results from this work are useful to help the government and hotel managers to take actions for improving the energy utilization and efficiency of the hospitality industry in Macau.
\end{abstract}

Keywords: energy efficiency; environmental protection; hospitality industry; Macau

\section{Introduction}

With a population of about 636,200 living in an area of $30.3 \mathrm{~km}^{2}$, Macau is one of the world's most attractive gaming cities. It is characterized by having a lot of hotels, and sufficient entertainment and convention facilities for the gaming and hospitality industry [1]. It is a location connecting the European countries and the East. Macau has undergone a rapid economic development since its return to the People's Republic of China in December 1999. Its gross domestic product (GDP) was increased by nearly nine-fold from 49,828 million Pataca (MOP) in 2000 to 443,298 million Pataca (MOP) equal to 55,551 US dollars in 2014 (the MOP/USD exchange rate was 7.98/1 in 2014) [2,3]. In addition, the number of visitors per year was increased from seven million in 2000 to 31.5 million in 2014 [4]. As a gaming center, the turnover of casinos in Macau in 2014 was 353.64 billion MOP (44.32 billion US dollars) [5], which was nearly seven times of the Las Vegas strip's takings in the same period (6.37 billion US dollars) [6]. The gaming and hospitality industry revenues account for more than 50 percent of Macau's GDP. Such a rapid development results in an enormous increase in environmental pollution and the consumption of resources and energy [7]. 
Now, Macau is building a world tourism and leisure center, paying great attention to the diversity of urban travel and leisure modes, such as cultural tours in Macau, sightseeing and shopping, large stage performances, luxury hotels and entertainment facilities, etc. [8]. By the end of 2014, the hospitality industry in Macau comprised 66 hotel units with 27,286 rooms and 71,291 beds [3]. Moreover, 18 new hotels were under construction.

With environment pollution, climate change, and global warming, sustainable development becomes a vitally important issue. Thus, in operating production systems, besides the consideration of productivity [9-16], people pay significant attention to cleaner production [17,18]. Also, studies are conducted to save energy in building operations $[19,20]$. For sustainable development in Macau, energy issues have attracted more and more attention in recent years due to the great effect of energy consumption on the environment. The primary concern is on energy consumption in commercial buildings since the commercial building sector is one of the largest energy consumers in Macau. It has been estimated that commercial buildings consumed more than 70 percent of Macau's energy in the past three years. Moreover, a large part of energy consumption is contributed by the gaming and hospitality industry [21]. According to the Office for the Development of the Energy Sector (GDSE) of Macau, the total energy consumption in Macau increased from 8293 TJ in 2009 to 15,270 TJ in 2014 [22]. Thus, the largest growth in energy consumption is due to the surge of electricity consumption in the gaming and hospitality industry.

As a pillar economy of Macau, the gaming and hospitality industry is energy-intensive [23]. Government policies have a significant effect on energy saving. To encourage large commercial users to conserve energy, Macau introduced a new tax system in 2014 as a macro control. By this new tax regime, the electric charge for large commercial users is increased by about $8 \%$ on average so as to promote its energy saving via a policy lever [24]. Besides, the Macau government plans to put forward more policies for the efficient energy utilization and to provide financial support to promote energy-efficient applications and research. Thus, it is necessary to investigate the status of energy efficiency, especially the one in the gaming and hospitality industry, such that the government can make the right decision on energy policy. However, there is no systematic investigation on this issue though lots of new large entertainment hotels have opened throughout Macau since the franchise opening of the gaming and hospitality industry in 2002.

In recent years, growing global environmental concerns are dictating the adoption of environment-friendly policies for buildings. Some well-known green building assessment systems that aim at environmental protection and sustainability have been developed, such as Green Star from Australia, Building Research Establishment Environmental Assessment Method (BREEAM) from British, Comprehensive Assessment System for Building Environmental Efficiency (CASBEE) from Japan, GB/T50378-2014 from China, and Leadership in Energy and Environmental Design (LEED) from the United States [25]. These systems consider both policies and actual operations for sustainable development. Among them, the LEED certification system is one of the most widely used assessment tools.

LEED, developed by the US Green Building Council (USGBC), is a comprehensive assessment system for performance of buildings, including building designing, operations and services of the existing buildings, and so on. There is a sub-system that is dedicated to operations of existing buildings for providing green services. Thus, as one of the most popular green building certification tools used worldwide, LEED is an appropriate choice for the evaluation of energy efficiency for an existing building. For the evaluation of energy efficiency in operating a building, studies on LEED are done to analyze the relationship between the credits [25] and the significance or performance of individual credits $[26,27]$. Also, some studies on LEED discuss the relationship between the scores and the individual credits, and how a high score can be achieved [28,29]. Most of these studies mainly focus on the evaluation of individual buildings by using LEED. Up to now, there is less research on the overall assessment of a set of buildings in a city or a region, which is a new topic and is significant to the government of a city and region for energy-saving renovation in existing buildings. This motivates us 
to conduct this study on evaluating the overall energy efficiency of the hotels in Macau since the hotels in Macau consume most of the energy. Notice that the government is responsible for the reduction of greenhouse gas emissions. It is vitally important for the Macau government to know the energy efficiency status so as to act properly.

This work investigates the status of energy efficiency of hotels as a whole in Macau in reference to LEED by mainly selecting credits from LEED, and adding a few indices that are special to Macau for this study. With significant efforts made by the Macau government to improve the energy efficiency in the hospitality industry in Macau, the aim of this study is to reveal the effect of the government efforts on the operations and services of hotels in Macau, this may be useful to the government for the green tourism city purpose.

\section{Methodology}

\subsection{The Indices}

This study is to evaluate the overall status of energy efficiency in Macau hospitality, but not to certificate an individual hotel. The key is to select proper evaluation indices such that they are suitable for the hotels in Macau as this is a case study. The principles that we use to select the indices mainly depend on whether an index is pertinent to the situation under investigation, or if the indices can be used for improving the energy efficiency in the future as well. Also, the framework of the indices should be internationally recognized. With these principles, we design the index system.

In building our index set, a large part of indices are selected from the credits in LEED. In the latest version of LEED, i.e., LEED v4, there is a sub-system designed for Building Operations and Maintenance $(\mathrm{O}+\mathrm{M})$, which is used for the certification of existing building facilities for educational, data centers, retail outlets, warehouse and distribution centers, and hospitality uses. The hospitality part is designed for performance evaluation for the existing hotels, motels, inns and other businesses within the service industry. Thus, it is meaningful to select some of the credits in the hospitality part in $\mathrm{O}+\mathrm{M}$ for this study. Figure A1 in the Appendix A gives the project checklist of LEED v4 O + M: Hospitality. We discuss how we select the credits in LEED for this work next.

There are studies that analyze the relationship among the LEED's credits. Ma and Cheng [25] explore the percentage of average score (PAS) of the credits in LEED. They identify the credits that can achieve higher PAS values with fewer efforts. Hence, for these credits, almost all the hotels can have a higher score. They include SSc5, IEQc2, IEQc3, and Inc2. In fact, for these credits, a higher score can be achieved by almost all the hotels in Macau. Thus, these credits with little effect on improving energy efficiency in the future are not considered in our study. Besides, some credits are about the alternative transportation, the improvement of plant and soil or integrated pest management only. Such credits include LTc1, SSc6, and IEQc9. They are not within the current scope on energy saving as well. Thus, they are not relevant to this study either.

Cracknell and Abu-Hijleh [30], and Ma and Cheng [25] identify credits for which a higher score is hard to achieve and lots of additional efforts are needed. They include EAc4 and EAc7. Thus, in general, a hotel does not have the enthusiasm to implement them by making the additional efforts. However, these credits may represent significant trends in energy saving and are the focus of government support as well. For example, EAc7 is for renewable energy and carbon offsets, which is an important issue in energy efficiency and greenhouse gas emission. Thus, these credits are included in this investigation.

Beside the indices that are selected from the credits in LEED, we add some special indices that have potentially significant effects on the energy efficiency improvement for Macau. We discuss these credits as follows.

- In the investigation, for energy conservation, some hotels have established a good mechanism to encourage their staff to propose new schemes to the hotel for energy saving. Also, some hotels have staff training programs to make sure that a piece of equipment is operated and maintained in an energy-efficient manner. According to the experiences from abroad, staff training is significant 
for improving energy efficiency [31]. Therefore, we add this index into the index set and it is denoted as ICc1.

- To support the low carbon-oriented transformation of commercial enterprises, improve air quality, and save energy, the Macau government established a fund called the "Environmental Protection and Energy Conservation Fund" [32,33] used to support projects for environmental protection in 2011. A hotel in Macau can take advantage of this by applying funding from it to improve its energy efficiency. Whether a hotel applies such a fund indicates its energy-saving awareness and behaviors. Thus, we take it as an index denoted as ICc2.

- Macau is located in a subtropical region and the weather is hot most of the time. Due to such a special weather environment, a hotel may grow green plants on its roof, which is called a green roof. With a green roof, the external heat is significantly isolated to save electricity consumption of air conditioners. This measure is more and more recognized worldwide. Thus, we take whether there is a green roof as an index and it is denoted as ICc3.

- There is a trend to encourage guests to change bed linen and towels every other day other than every day to save energy in hotels. Thus, there are different ways to do so for various hotels. For example, some hotels offer restaurant coupons as a reward if a guest does so. Hence, we take such a way for saving energy as an index and it is denoted as ICc4.

- The Macau government organizes different activities to promote energy conservation. For example, the Macau International Environmental Cooperation Forum \& Exhibition has been held every year since 2008 and the Macau Energy Conservation Week has been held every year since 2007. In addition, there are soap recycling and used clothes recycling community activities for public welfare. Surely, participation in these activities has a positive effect on energy saving. Thus, we take a hotel's participation in these activities as an index and it is denoted as ICc5.

\subsection{The Index System}

With the indices determined, we now discuss how to organize them. For certification, LEED evaluates a building by grading every index with a score. For the overview status of all hotels in Macau in this study, it is not necessary to give a score for every index for the hotels. Thus, for each index, we examine whether it is done or not by using yes (1) or no (0). By doing so, some credits in LEED can be merged into one here. We organize the indices as follows.

In this study, based on the above-determined indices, we group them such that a hierarchical evaluation system is built. The Macau government established the Macau Green Hotel Award to encourage energy saving in hotels. Since 2007, awards have been given to hotels that achieve significant improvements in energy saving. For this award, a hotel is evaluated in three areas: Green Leadership and Innovation (GLI), Green Program and Performance (GPP), and Partner Synergy (PS) [34]. We adopt them as three indices at the upper level. Then, the indices determined in the last sub-section are classified into three groups as shown in Table 1. The GLI contains five lower-level indices and we group these indices together as they save energy through operation. The GPP contains nine indices and their implementation requires the installation of some devices. Thus, we group them together. PS includes three indices that require cooperation with partners. For easy reference, the short descriptions of every indicator are given in brackets.

The relations between the indices given here and the ones determined in the last sub-section are shown in Table 1. For instance, GLIc2 corresponds to EAc7 that requires a hotel do carbon audits for effective energy management; GPPc4 corresponds to ICc3 for green roof practice; GPPc6 corresponds to IEQc5; and PSc2 contains MRc1, MRc2, and MRc3. These three credits in LEED deal with how to obtain energy-efficient products and services from suppliers and contractors and are merged to one. 
Table 1. The structure of the index set.

\begin{tabular}{|c|c|c|c|}
\hline $\begin{array}{l}\text { Indices at the } \\
\text { Upper Level }\end{array}$ & Indices at the Lower Level & $\begin{array}{l}\text { Corresponding } \\
\text { Credits in LEED }\end{array}$ & $\begin{array}{l}\text { Characteristic } \\
\text { Indices }\end{array}$ \\
\hline \multirow{4}{*}{$\begin{array}{l}\text { Green Leadership and } \\
\text { Innovation (GLI) }\end{array}$} & $\begin{array}{l}\text { GLIc1: the implementation of energy-saving and } \\
\text { environmental programs (environmental programs) }\end{array}$ & EAp3, EAc4 & / \\
\hline & $\begin{array}{l}\text { GLIc2: carbon auditing and implementation of } \\
\text { energy management (carbon audits) }\end{array}$ & EAc7 & / \\
\hline & $\begin{array}{l}\text { GLIc3: encouragement of staff's proposals on energy } \\
\text { conservation plan, and training of energy } \\
\text { conservation to staff members (staff training and } \\
\text { proposal adoption) }\end{array}$ & / & ICc1 \\
\hline & $\begin{array}{l}\text { GLIc4: applications for environmental protection \& } \\
\text { energy conservation fund (EPEC fund) }\end{array}$ & / & ICc2 \\
\hline \multirow{9}{*}{$\begin{array}{l}\text { Green Program and } \\
\text { Performance (GPP) }\end{array}$} & $\begin{array}{l}\text { GPPc1: the usage of shading devices to reduce direct } \\
\text { sunlight (shading devices) }\end{array}$ & IEQc4 & / \\
\hline & $\begin{array}{l}\text { GPPc2: the installation of water-saving showerheads } \\
\text { to reduce consumption (water-saving showerheads) }\end{array}$ & WEp1 & / \\
\hline & $\begin{array}{l}\text { GPPc3: the installation of system of waste water } \\
\text { recycling (waste water recycling) }\end{array}$ & WEc2 & / \\
\hline & $\begin{array}{l}\text { GPPc4: the adoption of a green roof to increase } \\
\text { building heat insulation (green roofs) }\end{array}$ & / & ICc3 \\
\hline & $\begin{array}{l}\text { GPPc5: the usage of energy-saving lighting to reduce } \\
\text { power consumption and the utilization rate is more } \\
\text { than } 50 \% \text { (energy-saving lighting) }\end{array}$ & EAc4, MRc2 & / \\
\hline & $\begin{array}{l}\text { GPPc6: the maximal use of natural light inside a } \\
\text { hotel (natural light) }\end{array}$ & IEQc5 & / \\
\hline & $\begin{array}{l}\text { GPPc7: the installation of timers or sensors of } \\
\text { lighting in corridor or office area (timers of lighting) }\end{array}$ & EAc4 & / \\
\hline & $\begin{array}{l}\text { GPPc8: adjusting air conditioning in low speed in } \\
\text { non-occupancy rooms (air conditioning setting) }\end{array}$ & IEQc3 & / \\
\hline & $\begin{array}{l}\text { GPPc9: the installation of motor efficiency controllers } \\
\text { for escalators and elevators (green lifts) }\end{array}$ & EAc4 & / \\
\hline \multirow{3}{*}{ Partner Synergy (PS) } & $\begin{array}{l}\text { PSc1: the reward to motivate guests to adopt green } \\
\text { practices (motivating green practices) }\end{array}$ & / & ICc4 \\
\hline & $\begin{array}{l}\text { PSc2: mechanisms for suppliers and contractors to } \\
\text { adopt environmental strategies (green suppliers) }\end{array}$ & $\begin{array}{l}\text { MRc1, MRc2, } \\
\text { MRc3 }\end{array}$ & / \\
\hline & $\begin{array}{l}\text { PSc3: participation in local activities of energy } \\
\text { conservation (attending green activities) }\end{array}$ & I & ICc5 \\
\hline
\end{tabular}

\subsection{Data Collection and Hotel Selection}

We use data relevant to hotel operations and economy from the official statistical materials issued by Macau Statistics and Census Service, such as Macau Yearbook [3], and Hotels and Similar Establishments Survey [35-37]. The data on energy saving and environmental protection of hospitality industry in Macau are collected from a field visiting survey of the selected hotels carried out by this research group, the official publications, and official website issued by Macau Environmental Protection Agency, such as the 5th anniversary special edition of Macau Green Hotel Award [38] and official pages of Macau Green Hotel Award [39].

The investigation took place from October 2015 to December 2015. To assess the overall energy efficiency of hotels in Macau, we evaluated the indices for different Star grades of hotels but not individual hotels. In Macau, there are 27 5-star hotels, 14 4-star hotels, 13 3-star hotels, and 12 2-star hotels. We randomly selected hotels from a list provided by the Macau Hotel Association to do this assessment. A total of 28 hotels were randomly selected in this study, accounting for $42.42 \%$ of the Macau hospitality industry [3]. The selected hotels are given in Table 2. By this selection, the percentage 
distribution of hotels of different categories within the four star categories is approximately equal. Thus, the samples are considered to be reasonably distributed in different groups and representative.

Table 2. The list of the sampled hotels.

\begin{tabular}{lllll}
\hline $\begin{array}{l}\text { Star } \\
\text { Category }\end{array}$ & $\begin{array}{l}\text { The Total } \\
\text { Number }\end{array}$ & $\begin{array}{l}\text { The Sampled } \\
\text { Number }\end{array}$ & $\begin{array}{l}\text { The Sampled } \\
\text { Percentage }\end{array}$ & The Sampled Hotels \\
\hline $5-$ Star & 27 & 11 & $40.7 \%$ & $\begin{array}{l}\text { MGM Macau, Sands Macau, Galaxy Macau, Altira Macau, Riviera } \\
\text { Hotel, The Venetian Macau, Mandarin Oriental Hotel, Grand } \\
\text { Lapa Macau, Grand Coloane Resort, Conrad Macau Cotai Central, } \\
\text { Sheraton Grand Macau Hotel }\end{array}$ \\
\hline $4-S t a r$ & 14 & 6 & $42.9 \%$ & $\begin{array}{l}\text { Hotel Beverly Plaza, Grandview Hotel, Hotel Golden Dragon, } \\
\text { Holiday Inn Macau, Pousada Marina Infante, Hotel Taipa Square }\end{array}$ \\
\hline 3-Star & 13 & 6 & $46.2 \%$ & $\begin{array}{l}\text { Waldo Hotel, Hotel Guia, Metropole Hotel, Grand Emperor Hotel, } \\
\text { Hotel Sintra Macau, Emperor Hotel Macau }\end{array}$ \\
\hline 2-Star & 12 & 5 & $41.7 \%$ & $\begin{array}{l}\text { East Asia Hotel, Central Hotel, Holiday Hotel, Hou Kong Hotel, } \\
\text { Hong Thai Hotel }\end{array}$ \\
\hline
\end{tabular}

\section{Results}

Based on the proposed evaluation index set, the energy performance of different star-level hotels is evaluated, as shown in Table 3. There is an apparent gap in energy saving performance between different star-level hotels. The higher the star-level of a hotel is, the higher enthusiasm on energy saving the hotel has. According to the results shown in Table 3, we can analyze the current energy utilization status so as to develop potential energy-saving measures, which is done as follows.

Table 3. The energy and environmental protection performance of the sampled hotels in Macau.

\begin{tabular}{|c|c|c|c|c|c|c|c|}
\hline \multirow{2}{*}{$\begin{array}{l}\text { Upper Level } \\
\text { Indices }\end{array}$} & \multirow{2}{*}{$\begin{array}{l}\text { Lower Level } \\
\text { Indices }\end{array}$} & \multicolumn{6}{|c|}{ Implementation/Adoption Rate } \\
\hline & & 2-Star & 3-Star & 4-Star & 5-Star & Total & $3,4,5$-Star \\
\hline \multirow{4}{*}{ GLI } & GLIc1 & $20 \%$ & $83.3 \%$ & $83.3 \%$ & $81.8 \%$ & $71.4 \%$ & $82.6 \%$ \\
\hline & GLIc2 & 0 & $16.7 \%$ & $33.3 \%$ & $63.6 \%$ & $35.7 \%$ & $43.5 \%$ \\
\hline & GLIc3 & 0 & $33.3 \%$ & $33.3 \%$ & $45.5 \%$ & $32.1 \%$ & $39.1 \%$ \\
\hline & GLIc4 & $60 \%$ & $83.3 \%$ & $100 \%$ & $81.8 \%$ & $82.1 \%$ & $87.0 \%$ \\
\hline \multirow{9}{*}{ GPP } & GPPc1 & $60 \%$ & $83.3 \%$ & $83.3 \%$ & $90.9 \%$ & $82.1 \%$ & $87.0 \%$ \\
\hline & GPPc2 & $40 \%$ & $83.3 \%$ & $83.3 \%$ & $100 \%$ & $82.1 \%$ & $91.3 \%$ \\
\hline & GPPc3 & 0 & $33.3 \%$ & $33.3 \%$ & $45.5 \%$ & $32.1 \%$ & $39.1 \%$ \\
\hline & GPPc4 & 0 & $33.3 \%$ & $16.7 \%$ & $36.4 \%$ & $25.0 \%$ & $30.4 \%$ \\
\hline & GPPc5 & $80 \%$ & $100 \%$ & $100 \%$ & $100 \%$ & $96.4 \%$ & $100 \%$ \\
\hline & GPPc6 & $80 \%$ & $83.3 \%$ & $100 \%$ & $100 \%$ & $92.9 \%$ & $95.7 \%$ \\
\hline & GPPc7 & $20 \%$ & $50 \%$ & $83.3 \%$ & $81.8 \%$ & $64.3 \%$ & $73.9 \%$ \\
\hline & GPPc8 & $60 \%$ & $83.3 \%$ & $100 \%$ & $100 \%$ & $89.3 \%$ & $95.7 \%$ \\
\hline & GPPc9 & 0 & $50 \%$ & $50 \%$ & $54.5 \%$ & $42.9 \%$ & $52.2 \%$ \\
\hline \multirow{3}{*}{ PS } & PSc1 & $20 \%$ & $33.3 \%$ & $33.3 \%$ & $36.4 \%$ & $32.1 \%$ & $34.8 \%$ \\
\hline & PSc2 & $20 \%$ & $100 \%$ & $66.7 \%$ & $36.4 \%$ & $53.6 \%$ & $60.9 \%$ \\
\hline & PSc3 & 0 & $50 \%$ & $50 \%$ & $36.4 \%$ & $35.7 \%$ & $43.5 \%$ \\
\hline
\end{tabular}

\subsection{Green Leadership and Innovation (GLI)}

For GLIc1 (environmental programs), we can see that $71.4 \%$ of hotels make significant efforts to implement energy-saving and environmental protection programs. Specifically, 81.8\% of 5-star hotels, $83.3 \%$ of 4 -star hotels, and $83.3 \%$ of 3 -star hotels adopt such measures. It is found that $82.6 \%$ of 3,4 , and 5-star hotels have done that such that energy conservation has been significantly improved in the 3, 4, and 5-star hotels over the past several years. Through the Macau Green Hotel Award organized by the Macau Environmental Protection Agency (DSPA) and co-organized by the Macau Government Tourist Office (DST) from 2007, we can see that the environmental protection performance of the 
awardees has been improved steadily year by year. It should be noted that there is no 2-star hotel that got an award before 2010. It follows from the data between 2008 and 2010 [38] that the awardees saved 8500 power units of electricity consumption per guestroom on average, which is equivalent to a reduction of $8470 \mathrm{~kg}$ of carbon emissions. Also, the awardees saved $90 \mathrm{~m}^{3}$ water consumption per guestroom on average, which is equivalent to a reduction of $18 \mathrm{~kg}$ of carbon emissions. On the contrary, only $20 \%$ of 2 -star hotels perform this index. The results indicate that the higher-star hotels do better in the implementation of energy-saving programs than the lower-star hotels. The possible reason is that the higher-star hotels have higher-level management standard and stronger environmental protection awareness.

With a very rapid increase in energy demands during the recent years in Macau [40], it is meaningful for the hotels in Macau to conduct carbon audits since, by doing so, the greenhouse gas emissions are clearly presented. As indicated by GLIc2 (carbon audits), the carbon audit provides the type, extent, and source of emissions from the business and reveals how greenhouse gas emissions can be reduced. By lowering emissions, a hotel is also beneficial in cost reduction and sale increase through improved marketing. Although it is not compulsory for a hotel to do carbon audits, it is found that $35.7 \%$ of hotels have done so. Specifically, $63.6 \%$ of 5 -star hotels do so to help them improve the energy policy and greenhouse gas emissions, which indicates that the managers of these hotels in Macau, especially the 5-star hotels, have higher environmental protection and energy-saving awareness. For instance, since 2008, through a series of measures of energy saving and environmental protection, the MGM Grand Macau successfully reduced $24 \%$ of total energy consumption, which is about 13.5 million kWh electricity utilization, leading to an indirect reduction of 9300 tons of carbon dioxide emissions [41]. However, it should be pointed out that only $16.6 \%$ of 3-star hotels do that, and no 2-star hotel does it. Hence, more efforts should be made for the hotels to do carbon audits so as to improve energy and environmental performance.

Staffs' energy-saving and environmental protection awareness reflect many aspects of energy utilization status, such as people's knowledge, personal consideration and behaviors, and the attitudes towards sustainable energy utilization and environmental protection. Since the contribution of staffs' awareness is enormous for energy efficiency improvement [31], it is very meaningful for a hotel to provide training for their workers to help the crews to accomplish their daily work in an energy-efficient manner as required by GLIc3 (staff training and proposal adoption). For instance, as significant amounts of water are used to clean guestrooms and public areas, Altira Macau trains its employees regularly and encourages them to reduce water use as far as possible by making use of alternative cleaning methods, like the use of alcohol-based hand cleaner. However, only 32.1\% of hotels in Macau have such training programs, especially there is no 2-star hotel that has such a program [42].

It is very meaningful for a hotel in Macau to apply for financial support from a government fund to improve energy-efficiency as indicated by GLIc4 (EPEC fund). The government of Macau SAR set up the "environmental protection and energy conservation fund" in 2011 to promote energy saving, environmental protection, and to encourage commercial enterprises and social organizations to use facilities and equipment that are environmentally friendly and efficient in energy and water saving [33]. In this study, it is found that $82.1 \%$ of hotels have submitted proposals or intend to apply for such funding for the purchase of energy conservation devices. According to statistical reports [43], up to May 2014, the government received about 5000 proposals, and 240 million MOP have been granted. The money was mainly used to replace $\mathrm{T} 8$ bulbs and air conditioners by $\mathrm{T} 5$ bulbs and energy-saving air conditioners. It is noticed that some of the 5-star hotels have already installed such devices when they were built, which moderately explains why the 5 -star hotels have a relatively lower adoption rate in this index than the average one.

\subsection{Green Program and Performance (GPP)}

Because Macau locates in a subtropical area, the installation of shading devices, such as curtains, heat insulating window film, and heat insulating glasses for hotel rooms, is very significant for 
reducing the indoor air-conditioning load [44]. Thus, it is meaningful to practice GPPc1 (shading devices). This study shows that $82.1 \%$ of hotels in Macau have installed such devices.

For GPPc2 (water-saving showerheads), the vast majority of sampled hotels $(82.1 \%)$ have installed water-saving showerheads to reduce water consumption. Especially, all the selected 5-star Hotels do that, and the average percentage of 3, 4 and 5-star hotels that do so is $91.3 \%$. Moreover, the effect of water saving is satisfactory via this method. For instance, by doing so, in 2010, Riviera Hotel Macau saved $10 \%$ of water compared with that in 2007. It is shown that about $600 \mathrm{MOP}$ expense of water can be saved for a single room [38].

For GPPc3 (waste water recycling), it requires hotels install wastewater recycling systems to save water, e.g., recycle wastewater for watering plants, or reuse pool water for toilet flushing. It is found that just $32.1 \%$ of hotels in Macau have installed such a kind of system. The percentage is $45.5 \%$ for 5 -star hotels, $33.3 \%$ for 4 -star hotels, 33.3\% for 3-star hotels, while no 2-star hotel does it. Thus, it is meaningful to make more hotels know the necessity of a wastewater reuse system for water resource protection, as well as the actual benefits for the hotel from saving water. Taking Grand Coloane Resort as an example, it installed a grey water recycling system such that around $70 \%$ of grey water is reused for garden irrigation, leading to that annual water consumption is reduced by $7 \%$ compared with that in the previous year [45].

Green Roof can increase amenity value, contribute to environmental qualities including urban heat island, air quality, and wildlife value, and enhance building energy performance ( $15 \%$ energy saving and 2 degrees Celsius room temperature reduction). For GPPc4 (green roofs), seven hotels build Green Roofs to increase building heat insulation and energy efficiency as shown in Figure 1. The percentage of hotels that do so is relatively low and is about $25.0 \%$. Four 5-star hotels have adopted the green roof strategy. In fact, Green Roof is very suitable for the densely populated area, like Macau, and its effectiveness has been verified in recent years [46].

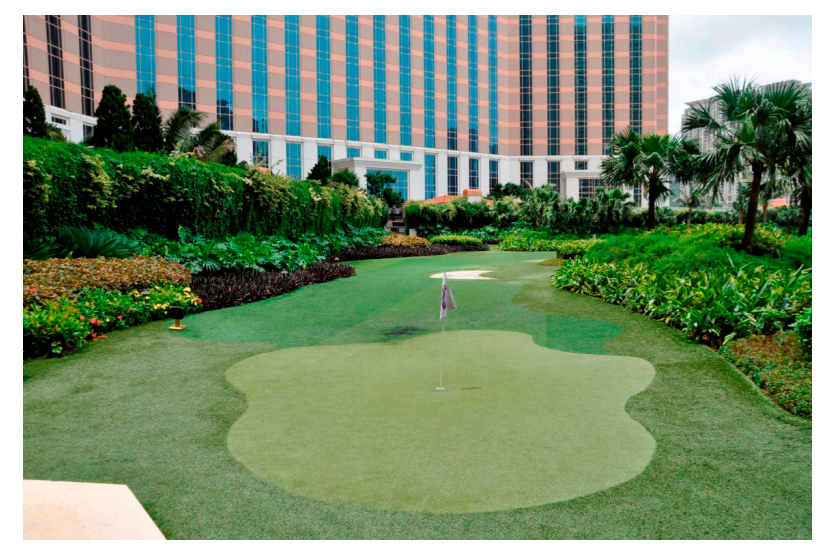

Figure 1. A Green Roof instance. (Provided by the Venetian Macau).

It is known that the reduction of power consumption for lightings has a remarkable effect on energy conservation. Thus, it is important to use energy-saving lightings devices as indicated by GPPc5 (energy-saving lightings). It is impressive that $96.4 \%$ of sampled hotels in Macau use energy-saving devices for lightings, and the utilization rate is more than $50 \%$. For example, Grand Lapa Macau has replaced all exterior neon signs with LED lights and thus energy is saved by about $58 \%$ [47]. Conrad Macau Cotai Central also changed all corridor lightings devices into LEDs in 2013, which can save about $646,000 \mathrm{kWh}$ of electricity each year [48]. Through field survey, we found that some 2-star hotels also installed energy-saving bulbs, but it lacks regular maintenance and there are unrepaired broken bulbs.

Natural light is the bounty of the earth's gift. The natural light utilization for lightings in a hotel can reduce energy consumption and is very comfortable for the visitors. For GPPc6 (natural 
light), $92.9 \%$ of hotels in Macau maximize the use of natural light for lightings inside a hotel or re-design a spatial arrangement of guest rooms to utilize the natural light as illustrated in Figure 2, which can achieve a perfect match between the natural lights and the building landscape for efficient energy utilization.

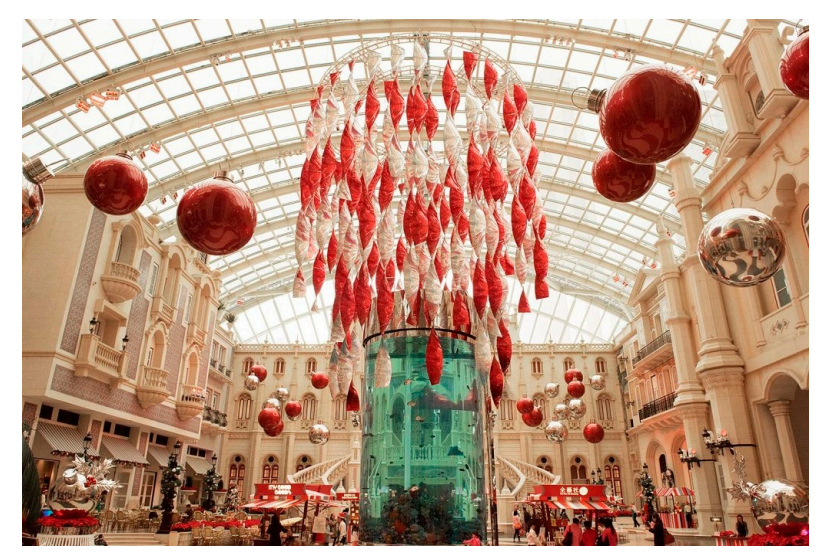

Figure 2. The natural-light filled atrium inside a hotel. (Provided by MGM Macau).

For GPPc7 (timers of lighting), more than $60 \%$ of sampled hotels installed timers and occupancy sensors to control the lightings devices in corridor or office areas to save power consumption. In contrast, only $20 \%$ of 2 -star hotels do so. Most of them are located in the old areas of the city where almost no auto-control lightings device is installed, and some of the lightings systems have not been renovated nearly five years.

According to Ali et al., 30\% or more electricity consumption is contributed by air conditioning systems [49]. Thus, it is vitally important to reduce energy consumption from air conditioning as indicated by GPPc8 (air conditioning setting). Nearly nine in 10 of sampled hotels operate their air conditioners in low speed and maintain the room temperature at a suitable level in non-occupancy guest rooms. For the air conditioning temperature setting, the average temperature in the hospitality industry has increased year by year. It was set to 24.2 degrees Celsius in 2013 that is 1.1 degrees Celsius higher than that in 2005 [50]. We found that most of the 2-star hotels did not have central air-conditioning systems. Some hanging air conditioning is timeworn and lacks regular maintenance, leading to a dramatic increase in energy consumption.

For GPPc9 (green lifts), 42.9\% of sampled hotels install advanced controllers in escalators and elevators to improve the energy efficiency. However, there is no 2-star hotel that installs such a controller. In the 2-star hotels, most of the elevators are old. Some of them install hanging air conditioning in lift cars. For such hotels, it is not only much more energy-consuming but also there is a potential security problem.

\subsection{Partner Synergy (PS)}

For PSc1 (motivating green practices), it is found that $32.1 \%$ of hotels in Macau take actions to encourage guests not to change bed linen and towels every day. For example, Hotel Guia encourages their guests to change towels every other day by offering $50 \%$ discount coupons for buying a drink in the hotel's shops or supermarkets [38]. Most hotels in Macau, however, did not have a similar measure. In fact, guests who practice environmental protection may prefer to do so [51].

For PSc2 (green suppliers), it requires hotels to buy products and services from suppliers and contractors who provide green goods and services. Such products mainly include environment-friendly detergents, CFCs (chlorofluorocarbons)-free refrigerants, biodegradable plastic bags, and cleaning fluid dispenser systems, etc. It shows that $53.6 \%$ of the sampled hotels purchase environment-friendly products and equipment, take every opportunity to make their suppliers and contractors know 
the importance of environmental management, and encourage them to adopt their environmental protection strategies. It should be noticed that some hotels do not respond positively to this index, including especially a few of 5-star hotels. For such hotels, it has a lower implementation rate than the average. In the future, hotel managers in Macau should pay more attention to this issue since the cooperation between hotels and green suppliers is one of the greatest challenges for them [52].

For PSc3 (attending green activities), it is found that only 35.7\% of hotels participate and support the environmental protection activities, such as The Macau International Environmental Cooperation Forum \& Exhibition (MIECF), the Macau Energy Conservation Week, the Soap Recycling Activity and the Used Clothes Recycling Program, etc., which implies that a large number of hotels in Macau are not active on this issue. Thus, it calls for more and more hotels to participate in these beneficial activities enthusiastically and the whole society should work together to practice energy saving and environmental protection.

\section{Discussion}

\subsection{Improvements in Energy Efficiency}

The energy consumption per unit economic benefit in the hospitality industry in Macau has been decreasing year by year according to the statistics [24]. It was 1010.4 MJ per thousand MOP in 2005 and, eight years later, it was reduced to 528.6 MJ per thousand MOP (in 2013). This is a significant advancement. Also, it shows that the Macau Green Hotel Award has an obvious effect on energy conservation. It is found that the electricity consumption in the awardee hotels has been reducing from 2007 to 2012 such that the average annual consumption per room is reduced by $25,000 \mathrm{kWh}$ of electricity in 2012 compared with that in 2007. Thus, for a 300-room hotel with an average of $75.5 \%$ (average data from the period of 2007-2012) occupancy rate, totally about 34 million $\mathrm{kWh}$ are saved during 2007-2012 [38]!

\subsection{Future Efforts for Improvement}

This investigation shows that most of the hotels in Macau have been making a vigorous and proactive effort to improve their green performance. However, there are some problems as discussed below.

- It follows from the results shown in Table 3 that some hotels have not taken any actions for the efficient energy saving yet. Thus, there is great potential to improve energy efficiency in the hospitality industry in Macau. Specifically, for most of the indices, there is an apparent gap in energy and environmental protection performance between 2-star hotels and 3, 4, 5-star hotels. The implementation rates of 2-star hotels are much lower than that of the other star-level sampled hotels. Thus, much more attention should be paid to the 2-star hotels in order to significantly improve their performance regarding energy saving and environmental protection.

- In this study, we find that the vast majority of 2-star hotels are located in the old parts of the city in Macau. During our visit, the managers of 2-star hotels said that most of their guests are individual travelers who would like to live in the old parts where most of the tourist sites locate. Besides, these hotels are small with fewer employees such that the daily workload is relatively heavy. Also, they spend less money and time to develop and implement energy-saving programs and activities. However, they indicate that if there is a suitable condition, they would like to do better in energy saving. Thus, the situation may be changed if the government can provide more guidance and financial support for them.

- In this study, we find that it is very difficult to get a report of energy consumption of a hotel in Macau, i.e., no hotel in Macau presents its energy consumption data to the public. If a hotel is required to publish its report on energy consumption to the public, there will be a strong motivation for the hotel to improve its energy efficiency. 
- Although the Office for the Development of the Energy Sector has been working together with several government departments to launch a pilot project on the solar photovoltaic system in Macau since 2010 [23], there was few renewable energy project for hotels in Macau. In fact, there is only one hotel that installed a wind turbine in 2012 [32] and no hotel did so after that. Hence, some incentive measures may be necessary to promote the pilot project of renewable energy sources in Macau. Some policies may be needed to encourage the development and applications of the newest technologies for energy efficiency and environmental protection continuously in the hospitality industry.

\section{Conclusions}

For sustainable development, there is an increasing concern about the energy efficiency issue. As Macau transforms from a Casino city to Green tourism city and promises to reduce greenhouse gas emissions, it is very important to know the status of energy efficiency in the hotels. This work conducts such an investigation by proposing an evaluation index system in reference to the LEED method. To make the investigation meaningful, we selected 28 hotels (eleven 5-star hotels, six 4-star hotels, six 3-star hotels, and five 2-star hotels) that include $42.42 \%$ of hotels in Macau.

With this investigation, it is shown that great efforts have been made for energy efficiency and environmental protection in Macau, such that energy consumption is significantly reduced. It is found that among the 16 indices, the implementation rate of seven indices is greater than $70 \%$ and the implementation rate of nine indices is more than $50 \%$. Also, there are six indices whose implementation rate is lower than $40 \%$. For most of the indices, the implementation rate of 5-star hotels is higher than the others. This implies that, generally, the 5-star hotels perform better than others. It is also shown that, among the 16 indices, the implementation rate of 11 indices for the 2-star hotels is lower or equal to $40 \%$ with the implementation rate of six indices being zero, which is generally bad. Thus, on the one hand, there is a long way to go for Macau to increase energy efficiency. However, on the other hand, it is shown that there are great potentials to improve energy efficiency if the hotels in Macau can act properly. Thus, the investigation is meaningful for the future improvement of energy efficiency and environmental protection.

Based on the results, we put forward some policy suggestions as follows:

Firstly, in order to optimize the environmental management of hospitality industry in Macau, it is urgent to improve the development of Green Hotel legal system and structure based on the existing environmental laws [23]. Also, for energy and environmental protection, it may be meaningful to make the status of energy consumption of the hotels under the public supervision. More specifically, a hotel should present its energy consumption report every year to the public. Some incentive measures and policies may be used to encourage a hotel to do so.

Secondly, due to that the performance of the 2-star hotels is not good, it is important for them to have the environmental awareness and improve energy efficiency. Supervision and management of 2-star hotels may be imposed for the 2-star hotels such that they can pay significant attention to energy efficiency.

Thirdly, for the 3, 4 and 5-star hotels, although significant efforts have been made such that energy efficiency has been improved, there are still significant potentials to do better. These hotels should be encouraged to use advanced information technology to improve their energy efficiency further since it has been shown that information technology can greatly reduce energy consumption in buildings.

Lastly, since renewable energy is significant in energy efficiency and environmental protection, it is vitally important to optimize the power structure by increasing the use of renewable energies such as solar and wind power [32].

Acknowledgments: This work was supported in part by Science and Technology development fund (FDCT) of Macau under Grant 106/2016/A3. 
Author Contributions: This investigation is mainly done by Ph. D. student $\mathrm{Xu}$ Wang under the supervision of Professor Naiqi Wu, while Yan Qiao and Qingbin Song help to collect a significant part of data and do data analysis. The paper is drafted by Xu Wang and revised by Naiqi Wu.

Conflicts of Interest: The authors declare no conflict of interest.

\section{Appendix A}

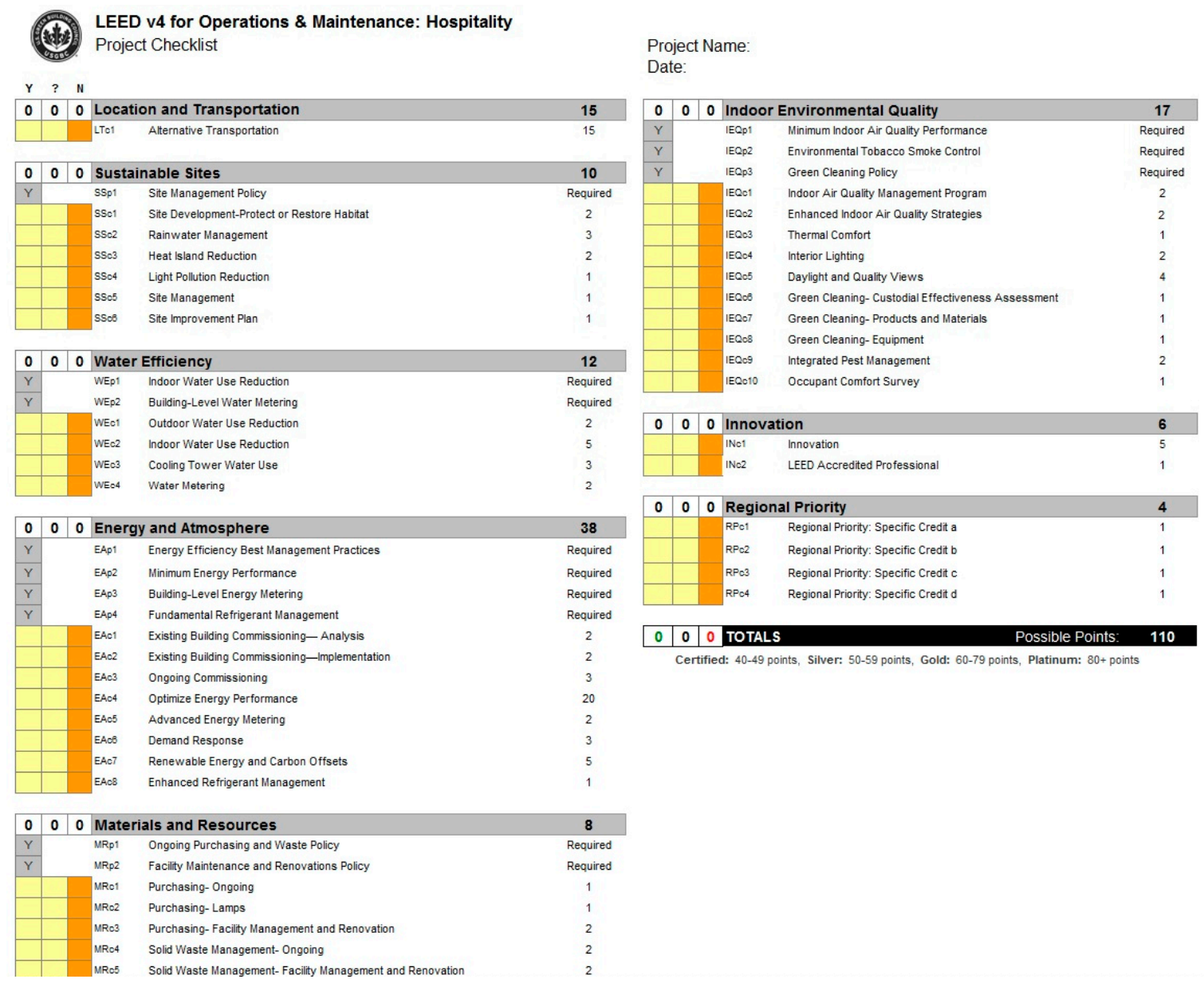

Figure A1. Leadership in Energy and Environmental Design (LEED) v4 for Building Operations and Maintenance: Hospitality_Project Checklist. Available online: http:/ / www.usgbc.org/resources / checklist-leed-v4-building-operations-and-maintenance (accessed on 6 June 2014).

\section{References}

1. Wan, Y.K. Assessing the strengths and weaknesses of Macau as an attractive meeting and convention destination: Perspectives of key informants. J. Conv. Event Tour. 2011, 12, 129-151. [CrossRef]

2. Statistics and Census Service of Macau (DSEC). Yearbook of Statistics 2000, 1st ed.; Statistics and Census Service of Macau: Macau, China, 2000; p. 363.

3. Statistics and Census Service of Macau (DSEC). Yearbook of Statistics 2014, 1st ed.; Statistics and Census Service of Macau: Macau, China, 2014; p. 341.

4. Statistics and Census Service of Macau (DSEC). Yearbook of Statistics 2015, 1st ed.; Statistics and Census Service of Macau: Macau, China, 2015; p. 156.

5. Statistics and Census Service of Macau (DSEC). Gaming Sector Survey 2014, 1st ed.; Statistics and Census Service of Macau: Macau, China, 2014; p. 3.

6. Las Vegas Year-to-Date Executive Summary in the Year of 2014. Available online: http://www.lvcva.com/ includes/content/images/media/docs/ES-YTD-2014.pdf (accessed on 9 June 2015). 
7. Ku, K.I.; Lai, T.M.; To, W.M. The relationship and impacts of sustainable tourism on environmental resource consumptions-The case of Macau SAR, China. In Proceedings of the 8th Conference on Sustainable Development of Energy, Water, and Environment Systems, Dubrovnik, Croatia, 22-27 September 2013; pp. 22-27.

8. Li, J.S.; Alsaed, A.; Hayat, T.; Chen, G.Q. Energy and carbon emission review for Macau's gaming industry. Renew. Sustain. Energy Rev. 2014, 29, 744-753. [CrossRef]

9. Wu, N.Q.; Zhou, M.C. Modeling, analysis and control of dual-arm cluster tools with residency time constraint and activity time variation based on Petri nets. IEEE Trans. Autom. Sci. Eng. 2012, 9, 446-454.

10. Wu, N.Q.; Zhou, M.C. Schedulability analysis and optimal scheduling of dual-arm cluster tools with residency time constraint and activity time variation. IEEE Trans. Autom. Sci. Eng. 2012, 9, 203-209.

11. Wu, N.Q.; Chu, F.; Chu, C.B.; Zhou, M.C. Petri net modeling and cycle time analysis of dual-arm cluster tools with wafer revisiting. IEEE Trans. Syst. Man Cybern. Syst. 2013, 43, 196-207. [CrossRef]

12. Wu, N.Q.; Zhou, M.C.; Bai, L.P.; Li, Z.W. Short-term scheduling of crude oil operations in refinery with high fusion point oil and two transportation pipelines. Enterp. Inf. Syst. 2016, 10, 581-610. [CrossRef]

13. Bai, L.P.; Wu, N.Q.; Li, Z.W.; Zhou, M.C. Optimal one-wafer cyclic scheduling and buffer space configuration for single-arm multicluster tools with linear topology. IEEE Trans. Syst. Man Cybern. Syst. 2016, 46, 1456-1467. [CrossRef]

14. Yang, F.J.; Wu, N.Q.; Qao, Y.; Zhou, M.C.; Li, Z.W. Scheduling of single-arm cluster tools for an atomic layer deposition process with residency time constraints. IEEE Trans. Syst. Man Cybern. Syst. 2017, 47, 502-516. [CrossRef]

15. Zhang, S.W.; Wu, N.Q.; Li, Z.W.; Qu, T.; Li, C.D. Petri net-based approach to short-term scheduling of crude oil operations with less tank requirement. Inf. Sci. 2017, 417, 247-261. [CrossRef]

16. Hou, Y.; Wu, N.Q.; Zhou, M.C.; Li, Z. W. Pareto-optimization for scheduling of crude oil operations in refinery via genetic algorithm. IEEE Trans. Syst. Man Cybern. Syst. 2017, 47, 517-530. [CrossRef]

17. Wang, S.; Liu, M.; Chu, F.; Chu, C. Bi-objective optimization of a single machine batch scheduling problem with energy cost consideration. J. Clean. Prod. 2016, 137, 1205-1215. [CrossRef]

18. Wu, N.Q.; Li, Z.W.; Qu, T. Energy efficiency optimization in scheduling crude oil operations of refinery based on linear programming. J. Clean. Prod. 2017, 166, 49-57. [CrossRef]

19. Zhao, Q.; Zhao, Y.; Wang, F.; Wang, J.; Jiang, Y.; Zhang, F. A data-driven method to describe the personalized dynamic thermal comfort in ordinary office environment: From model to application. Build. Environ. 2014, 72, 309-318. [CrossRef]

20. Wang, X.; Qiao, Y.; Wu, N.Q.; Li, Z.W.; Qu, T. On optimization of thermal sensation satisfaction rate and energy efficiency of public rooms: A case Study. J. Clean. Prod. 2017, 176, 990-998. [CrossRef]

21. Comprehensive Information of Energy and Service in the Period of 2008-1014. Available online: http: / / www.gdse.gov.mo/gdse_big/table.asp?tableId=5 (accessed on 8 May 2015).

22. 2009-2014 Total Amount of Energy Consumption According to the Types of Statistical. Available online: http:/ / www.gdse.gov.mo/gdse_big/table.asp?tableId=1 (accessed on 8 May 2015).

23. Macau Environmental Protection Agency (DSPA). 2012-2013 Report on the State of the Environment of Macau, 1st ed.; Macau Environmental Protection Agency: Macau, China, 2014; p. 6.

24. Office for the Development of the Energy Sector of Macau (GDSE). The Newsletter of the Office for the Development of the Energy Sector 2013, 1st ed.; Office for the Development of the Energy Sector of Macau: Macau, China, 2013; p. 4.

25. Ma, J.; Cheng, C.P. Data-driven study on the achievement of LEED credits using percentage of average score and association rule analysis. Build. Environ. 2016, 98, 121-132. [CrossRef]

26. Cheng, C.P.; Ma, J. A Non-linear case-based reasoning approach for retrieval of similar cases and selection of target credits in LEED projects. Build. Environ. 2015, 93, 349-361. [CrossRef]

27. Reinhart, C.F. Opinion: Climate-based daylighting metrics in LEEDv4-A fragile progress. Light. Res. Technol. 2015, 47, 388. [CrossRef]

28. Kucukvar, M.; Egilmez, G.; Tatari, O. Life cycle assessment and optimization-based decision analysis of construction waste recycling for a LEED-certified university building. Sustainability 2016, 8, 89. [CrossRef]

29. Xuan, X.D. Effectiveness of indoor environment quality in LEED-certified healthcare settings. Indoor Built Environ. 2016, 25, 786-798. [CrossRef] 
30. Cracknell, T.M.; Abu-Hijleh, B. Measuring LEED-NC applicability in design for hospitality. Front. Archit. Res. 2015, 4, 308-317. [CrossRef]

31. Maria, R.; Javier, L.I.; Javier, R.P. Drivers of environmental innovation in Majorcan hotels. J. Sustain. Tour. 2015, 23, 1529-1549.

32. Macau Environmental Protection Agency (DSPA). Environmental Protection Planning of Macau (2010-2020), 1st ed.; Macau Environmental Protection Agency: Macau, China, 2014; p. 31.

33. Macau Environmental Protection Agency (DSPA). Annual Work Report, 1st ed.; Macau Environmental Protection Agency: Macau, China, 2013; pp. 45-47.

34. Macau Environmental Protection Agency (DSPA). Macau Green Hotel Award Application Guideline, 1st ed.; Macau Environmental Protection Agency: Macau, China, 2015; p. 8.

35. Statistics and Census Service of Macau (DSEC). Hotels and Similar Establishments Survey, 1st ed.; Statistics and Census Service of Macau: Macau, China, 2012.

36. Statistics and Census Service of Macau (DSEC). Hotels and Similar Establishments Survey, 1st ed.; Statistics and Census Service of Macau: Macau, China, 2013.

37. Statistics and Census Service of Macau (DSEC). Hotels and Similar Establishments Survey, 1st ed.; Statistics and Census Service of Macau: Macau, China, 2014.

38. Macau Environmental Protection Agency (DSPA). Macau Green Hotel Award 5th Anniversary Special Edition, 1st ed.; Macau Environmental Protection Agency: Macau, China, 2012.

39. Macau Green Hotel Award. 2016. Available online: http://www.dspa.gov.mo/h_index.aspx (accessed on 3 June 2016).

40. Li, J.S.; Chen, G.Q. Energy and greenhouse gas emissions review for Macau. Renew. Sustain. Energy Rev. 2013, 22, 23-32. [CrossRef]

41. MGM Macau Support “Earth Hour 2015" Lights Out of Action, Hand in Hand to Create a Green City. Available online: https:/ / www.mgmmacau.com/node/10427 (accessed on 28 March 2015).

42. Melco International Development Limited Corporate Social Responsibility Report. 2014. Available online: http:/ / www.melco-group.com/doc/csr/2014/en/index.html (accessed on 1 March 2015).

43. Environmental Protection and Energy Saving Funds Accumulated Subsidy MOP 240 Million. Available online: http:/ / www.Macaudaily.com/html/2014-06/14/content_910626.htm (accessed on 14 June 2014).

44. Ismael, R.M.; Juan, L.F.B.; Francisco, J.G.G.; Paloma, R.C.F. Influence of selected solar positions for shading device calculations in building energy performance simulations. Energy Build. 2015, 101, 144-152.

45. Macau Green Hotel Awardees 2013-Awarded Hotels: Grand Coloane Resort. Available online: http: / /www.dspa.gov.mo/h_award_detail.aspx?a_id=100887\# (accessed on 13 April 2015).

46. Anna, L.P.; Cristina, P.F.C. Thermal-physics and energy performance of an innovative green roof system: The Cool-Green Roof. Sol. Energy 2015, 116, 337-356.

47. Macau Green Hotel Awardees 2013-Awarded Hotels: Grand Lapa Macau. Available online: http:/ / www. dspa.gov.mo/h_award_detail.aspx?a_id=100885\# (accessed on 7 April 2015).

48. Conrad Macau's Green Resolution in the Year of 2013, Hilton Worldwide. Available online: http:/ / news. hiltonworldwide.com/index.cfm/newsroom/detail/22727 (accessed on 22 January 2013).

49. Ali, Y.; Mustafa, M.; Al-Mashaqbah, S.; Mashal, K.; Mohsen, M. Potential of energy savings in the hotel sector in Jordan. Energy Convers. Manag. 2008, 49, 3391-3397. [CrossRef]

50. Office for the Development of the Energy Sector of Macau (GDSE). The Research Report of Energy Efficiency Status in 2013, 1st ed.; Office for the Development of the Energy Sector: Macau, China, 2013; p. 3.

51. Barber, N.A. Profiling the Potential "Green" Hotel Guest: Who Are They and What Do They Want. J. Hosp. Tour. Res. 2012, 38, 361-387. [CrossRef]

52. Lee, K.H.; Mahdi, M.; Reza, F.S. Technical, environmental and eco-efficiency measurement for supplier selection: An extension and application of data envelopment analysis. Int. J. Prod. Econ. 2015, 168, 279-289.

(C) 2018 by the authors. Licensee MDPI, Basel, Switzerland. This article is an open access article distributed under the terms and conditions of the Creative Commons Attribution (CC BY) license (http://creativecommons.org/licenses/by/4.0/). 